\title{
Unprecedented enantioselectivity in a cluster-based catalytic system
}

\author{
Viktor Moberg, Matti Haukka, Igor O. Koshevoy, Roberto Ortiz \\ and Ebbe Nordlander ${ }^{*}$
}

\section{SUPPORTING INFORMATION}

\section{Synthesis of $\left[\mathrm{H}_{4} \mathrm{Ru}{ }_{4}(\mathrm{CO})_{10}\left\{(\mathrm{R})-1-\left[(\mathrm{R})-2-\left(2^{\prime}-\right.\right.\right.\right.$ diphenylphosphinophenyl)ferrocenyl]-ethyldi(bis-3,5-}

\section{trifluoromethyl-phenyl)-phosphine\}]}

In a typical experiment, $\quad\left[\mathrm{H}_{4} \mathrm{Ru}_{4}(\mathrm{CO})_{12}\right] \quad(25 \quad \mathrm{mg}, \quad 34 \quad \mu \mathrm{mol}) \quad$ and $\quad(\mathrm{R})-1-\left[(\mathrm{R})-2-\left(2^{\prime}-\right.\right.$ diphenylphosphinophenyl)ferrocenyl]ethyldi(bis-3,5-trifluoromethyl-phenyl)-phosphine (W001) (60 mg, $65 \mu \mathrm{mol}$ ) was suspended in benzene $\left(15 \mathrm{ml}\right.$, degassed) and kept under inert atmosphere. A total of $9 \mathrm{mg} \mathrm{Me}_{3} \mathrm{NO} * 2 \mathrm{H}_{2} \mathrm{O}(81$ $\mu$ mol, 1.5 equiv) was dissolved in methanol ( $5 \mathrm{ml}$, degassed) and added dropwise to the above-mentioned suspension over a period of 20 minutes. The reaction mixture was stirred for $10 \mathrm{hrs,} \mathrm{yielding} \mathrm{a} \mathrm{deep} \mathrm{red} \mathrm{solution.}$ The solvent was removed under vacuum. The red solid obtained was dissolved in a minimum quantity of $\mathrm{CH}_{2} \mathrm{Cl}_{2}$ and the products were separated using preparative TLC (commercial $20 \times 20 \mathrm{~cm}$ plates covered with Merck kieselgel $60,0.25 \mathrm{~mm}$ thickness) with a hexane $/ \mathrm{CH}_{2} \mathrm{Cl}_{2}$ (1/1 v:v) mixture as eluent. Besides the brown decomposition material that could be observed at the line of application, two products were isolated and characterized as (in order of appearance on the TLC plate) $\left[\mathrm{H}_{4} \mathrm{Ru}_{4}(\mathrm{CO})_{10}\{1,1-\mathrm{W} 001\}\right]$ (yield $6 \mathrm{mg}, 7 \%$ ) and $\left[\mathrm{H}_{4} \mathrm{Ru}_{4}(\mathrm{CO})_{10}\{\mu\right.$-1,2-W001 $\left.\}\right]$ (yield $59 \mathrm{mg}, 68 \%$ ).

$\left[\mathrm{H}_{4} \mathrm{Ru}_{4}(\mathrm{CO})_{10}\{\mu-1,2-\mathrm{W} 001\}\right] 1 \mathrm{red}$ solid- IR $v(\mathrm{CO}) / \mathrm{cm}^{-1},\left(\mathrm{CH}_{2} \mathrm{Cl}_{2}\right): 2073 \mathrm{~ms}, 2053 \mathrm{~ms}, 2028 \mathrm{vs}, 2013 \mathrm{~s}, 1998 \mathrm{w}$,

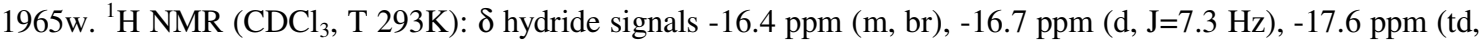
$\mathrm{J}=11 \mathrm{~Hz}, \mathrm{~J}=2.4 \mathrm{~Hz}),-18.5(\mathrm{dm}, \mathrm{br}, \mathrm{J}$ ca. $30 \mathrm{~Hz}) .{ }^{31} \mathrm{P}\left\{{ }^{1} \mathrm{H}\right\} \mathrm{NMR}\left(\mathrm{CDCl}_{3}, \mathrm{~T} 293 \mathrm{~K}\right): \delta 45.9 \mathrm{ppm}(\mathrm{m}), 39.1 \mathrm{ppm}(\mathrm{m})$. MS $\left(\mathrm{FAB}^{+}\right) 1620\left(\mathrm{M}^{+}\right)$Anal calcd for $\mathrm{C}_{56} \mathrm{H}_{36} \mathrm{O}_{10} \mathrm{~F}_{12} \mathrm{P}_{2} \mathrm{FeRu}_{4} \cdot 1 / 2 \mathrm{C}_{6} \mathrm{H}_{14}: \mathrm{C}, 42.60 ; \mathrm{H}, 2.59 \%$. Found: $\mathrm{C}, 42.50 ; \mathrm{H}$, $2.83 \%$.

*To whom correspondence should be addressed. Fax: (+46) 46222 0310. E-mail: Ebbe.Nordlander@chemphys.lu.se. 
$\left[\mathrm{H}_{4} \mathrm{Ru}_{4}(\mathrm{CO})_{10}\{1,1-\mathrm{W} 001\}\right] 2$ orange solid- IR v(CO)/cm ${ }^{-1},\left(\mathrm{CH}_{2} \mathrm{Cl}_{2}\right): 2078 \mathrm{~ms}, 2049 \mathrm{~s}, 2027 \mathrm{vs}, 2003 \mathrm{~ms}, 1986 \mathrm{mw}$, 1965w 1949w. ${ }^{1} \mathrm{H}$ NMR $\left(\mathrm{CDCl}_{3}\right.$, T 293K): $\delta$ hydride signals $-15.7 \mathrm{ppm}(\mathrm{s}, \mathrm{br}),-16.0 \mathrm{ppm}(\mathrm{t}, \mathrm{J}=7.8 \mathrm{~Hz}),-16.5$ ppm (m, br), -16.9 (s, br), -17.5 (s, br), -17.8 (s, br). ${ }^{31} \mathrm{P}\left\{{ }^{1} \mathrm{H}\right\} \mathrm{NMR}\left(\mathrm{CDCl}_{3}, \mathrm{~T} 293 \mathrm{~K}\right): \delta 43.3 \mathrm{ppm}(\mathrm{m}), 4.3 \mathrm{ppm}$ (m).

\section{Synthesis of $\quad\left[\mathrm{H}_{4} \mathrm{Ru}_{4}(\mathrm{CO})_{10}\left\{(\mathrm{R})-1-\left[(\mathrm{R})-2-\left(2^{\prime}-\right.\right.\right.\right.$ Diphenyl- phosphino-phenyl)ferrocenyl]-ethyldiphenyl- phosphine\}]}

The synthesis and work-up procedure for these clusters are identical to that described above. $\left[\mathrm{H}_{4} \mathrm{Ru}_{4}(\mathrm{CO})_{12}\right](25$ mg, $34 \mu \mathrm{mol}$ ) and (R)-1-[(R)-2-(2'-Diphenyl- phosphino-phenyl)-ferrocenyl]ethyldiphenyl-phosphine (W002) (43 mg, $65 \mu \mathrm{mol}$ ) was suspended in benzene (15ml, degassed) and kept under inert atmosphere. A total of $9 \mathrm{mg}$ $\mathrm{Me}_{3} \mathrm{NO} * 2 \mathrm{H}_{2} \mathrm{O}(81 \mu \mathrm{mol}, 1.5$ equiv) was dissolved in methanol (5 ml, degassed) and added dropwise. The reaction mixture was stirred for $6 \mathrm{hrs}$, yielding a deep red solution. The solvent was removed under vacuum. The red solid obtained was dissolved in a minimum quantity of $\mathrm{CH}_{2} \mathrm{Cl}_{2}$ and the products were separated using preparative TLC (commercial $20 \times 20 \mathrm{~cm}$ plates covered with Merck kieselgel 60, $0.25 \mathrm{~mm}$ thickness) with a hexane $/ \mathrm{CH}_{2} \mathrm{Cl}_{2}$ (1/1 v:v) mixture as eluent. Besides some brown decomposition material that could be observed at the line of application, two products were isolated and characterized as (in order of appearance on the TLC plate) $\left[\mathrm{H}_{4} \mathrm{Ru}_{4}(\mathrm{CO})_{10}\{1,1-\mathrm{W} 002\}\right]$ (yield $3 \mathrm{mg}, 4 \%$ ) and $\left[\mathrm{H}_{4} \mathrm{Ru}_{4}(\mathrm{CO})_{10}\{\mu-1,2-\mathrm{W} 002\}\right]$ (yield $45 \mathrm{mg}, 62 \%$ )

$\left[\mathrm{H}_{4} \mathrm{Ru}_{4}(\mathrm{CO})_{10}\{\mu-1,2-\mathrm{W} 002\}\right] 3-\mathrm{IR} v(\mathrm{CO}) / \mathrm{cm}^{-1},\left(\mathrm{CH}_{2} \mathrm{Cl}_{2}\right): 2075 \mathrm{~s}, 2055 \mathrm{~s}, 2020 \mathrm{vs}, 2010 \mathrm{~ms}, 1995 \mathrm{mw}, 1965 \mathrm{w} .{ }^{1} \mathrm{H}$ NMR $\left(\mathrm{CDCl}_{3}, \mathrm{~T} 293 \mathrm{~K}\right): \delta$ hydride signals $-16.70 \mathrm{ppm}(\mathrm{s}, \mathrm{br}),-16.77 \mathrm{ppm}(\mathrm{d}, \mathrm{J}=4.9 \mathrm{~Hz}),-16.98 \mathrm{ppm}(\mathrm{td}, \mathrm{J}=10.4$ $\mathrm{Hz}, \mathrm{J}=1.6 \mathrm{~Hz}$ ), -17.82 (br), -17.82 (br), 18,02 (br) ${ }^{31} \mathrm{P}\left\{{ }^{1} \mathrm{H}\right\} \mathrm{NMR}\left(\mathrm{CDCl}_{3}, \mathrm{~T} 293 \mathrm{~K}\right): \delta 42.3 \mathrm{ppm}(\mathrm{m}), 35.2 \mathrm{ppm}$ (m).

$\left[\mathrm{H}_{4} \mathrm{Ru}_{4}(\mathrm{CO})_{10}\{1.1-(\mathrm{W} 002)\}\right] 4-\mathrm{IR} v(\mathrm{CO}) / \mathrm{cm}^{-1},\left(\mathrm{CH}_{2} \mathrm{Cl}_{2}\right): 2074 \mathrm{~ms}, 2045 \mathrm{~s}, 2021 \mathrm{vs}, 2000 \mathrm{~m}, 1983 \mathrm{mw}, 1961 \mathrm{w} .{ }^{1} \mathrm{H}$ $\mathrm{NMR}\left(\mathrm{CDCl}_{3}, \mathrm{~T} 293 \mathrm{~K}\right): \delta$ hydride signals $-16.8 \mathrm{ppm}(\mathrm{s}, \mathrm{br}),-17.0 \mathrm{ppm}(\mathrm{m}, \mathrm{br}),-17.8 \mathrm{ppm}(\mathrm{s}, \mathrm{br}) .{ }^{31} \mathrm{P}\left\{{ }^{1} \mathrm{H}\right\} \mathrm{NMR}$ $\left(\mathrm{CDCl}_{3}, \mathrm{~T} 293 \mathrm{~K}\right): \delta 45.7 \mathrm{ppm}(\mathrm{m}), 38.5 \mathrm{ppm}(\mathrm{m})$. 


\section{Catalyic experiment}

In a typical reaction, an autoclave (Carl Roth) was loaded with catalyst (10 mg) and substrate (250 or 500 molar excess) under $\mathrm{N}_{2}$, and the degassed solvent mixture was added (2.5 mL EtOH/2.5 mL toluene). The reaction vessel was closed and purged several times with hydrogen before final pressurizing to 50 bars. The reaction mixture was continuously stirred with a magnetic stirrer (ca. $800 \mathrm{rpm}$ ) and heated at $100{ }^{\circ} \mathrm{C}$ for $24 \mathrm{hrs}$. After a cooling period of approx. $30 \mathrm{~min}$., the reaction vessel was carefully depressurized and opened. The homogeneous reaction mixture was transferred to a $50 \mathrm{~mL}$ flask and concentrated under vacuum. The conversions for the catalysis runs were calculated on the basis of NMR analyses. To separate the carboxylic acid from the cluster, the reaction residue was dissolved in $\mathrm{Et}_{2} \mathrm{O}(5 \mathrm{ml})$ and the carboxylic acid was extracted with $\mathrm{NaH}(\mathrm{CO})_{3}$ (sat. $\left.3 * 10 \mathrm{ml}\right)$ and washed with $\mathrm{Et}_{2} \mathrm{O}(2 * 5 \mathrm{ml})$. The carboxylate was protonated with $\mathrm{H}_{2} \mathrm{SO}_{4}$ (conc., q.s) and extracted with $\mathrm{Et}_{2} \mathrm{O}(3 * 10 \mathrm{ml})$ and washed with $\mathrm{H}_{2} \mathrm{O}(2 * 5 \mathrm{ml})$ and dried over $\mathrm{Na}_{2} \mathrm{SO}_{4}$. The $\mathrm{Et}_{2} \mathrm{O}$ was removed under vacuum yielding the carboxylic acid quantitatively. The $\mathrm{Et}_{2} \mathrm{O}$ in which the carboxylic acid was separated from the cluster, was evaporated under reduced pressure to recover the cluster. In certain cases, where formation of ester during the catalytic experiment was observed, the recovered cluster was dissolved in a minimum quantity of $\mathrm{CH}_{2} \mathrm{Cl}_{2}$ and the products were separated using preparative TLC (commercial $20 \mathrm{x} 20 \mathrm{~cm}$ plates covered with Merck kieselgel $60,0.25 \mathrm{~mm}$ thickness) with a hexane $/ \mathrm{CH}_{2} \mathrm{Cl}_{2}(1 / 1 \mathrm{v}: \mathrm{v})$ mixture as eluent. Usually $60-70 \%$ of the cluster was recovered after a catalytic run.

\section{Mercury Poisoning Experiment/ Determination of turn over frequency}

The experimental setup follows the above described procedure for catalytic experiment, except that approximately 2 grams (20 grams in TON experiment) of metallic mercury is added to the reaction mixture before the autoclave is sealed and pressurised. After a complete catalytic run, the $\mathrm{Hg}$ had acquired a faint grey film on some parts of its surface. Products were separated and analysed as mentioned above.

Determination of Enantiomeric excess. 
The enantiomeric excess of the product was detected by converting the reduced carboxylic acid with (S)-methyl mandelate and analyzing the diastereomeric mixture by NMR, as described in E. Tyrell, M. W. H. Tsang, G. A. Skinner, J. Fawcett, Tetrahedron. 1996, 29, 9841. It was found that chromatography of the final product(s) was not necessary.

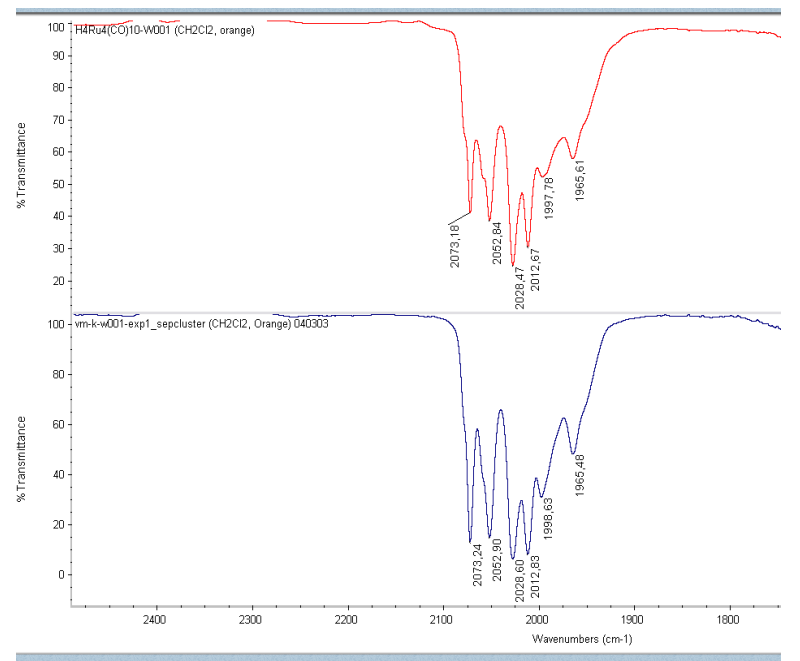

Figure S1. IR spectra of $\left[\mathrm{H}_{4} \mathrm{Ru}_{4}(\mathrm{CO})_{10}\{\mu-1,2-\mathrm{W} 001\}\right]$ (top), and recovered $\left[\mathrm{H}_{4} \mathrm{Ru}_{4}(\mathrm{CO})_{10}\{\mu-1,2-\mathrm{W} 001\}\right]$ (bottom) after catalytic experiment. 


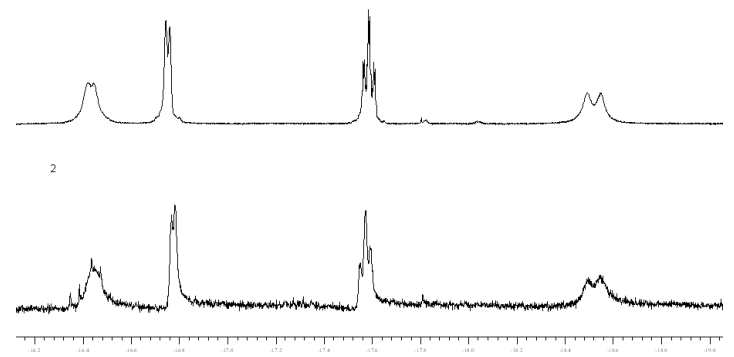

Figure S2. Hydride regions of ${ }^{1} \mathrm{H}-\mathrm{NMR}$ spectra of $\left[\mathrm{H}_{4} \mathrm{Ru}_{4}(\mathrm{CO})_{10^{-}}\{\mu-1,2-\mathrm{W} 001\}\right]$ (top) and recovered catalyst (bottom). Data collected at $298 \mathrm{~K}$ in $\mathrm{CDCl}_{3}$.

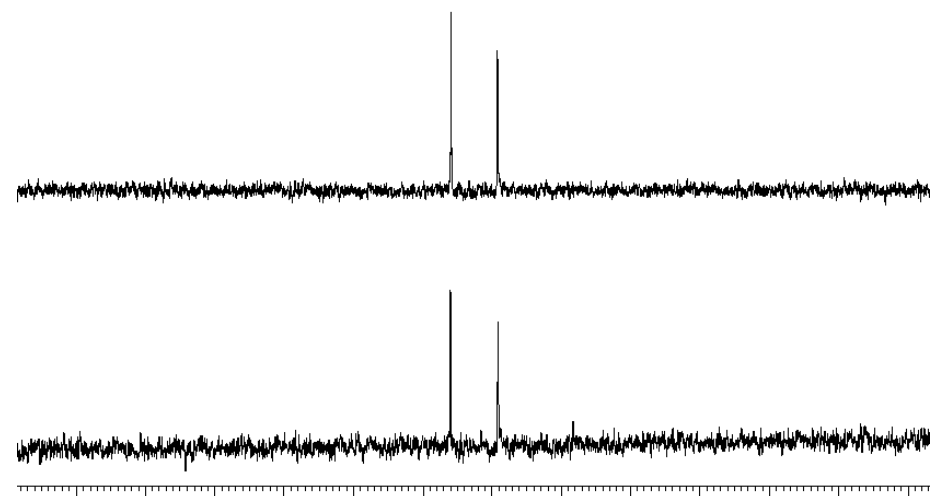

Figure S3. ${ }^{31} \mathrm{P}\left\{{ }^{1} \mathrm{H}\right\}-\mathrm{NMR}$ spectra of $\left[\mathrm{H}_{4} \mathrm{Ru}_{4}(\mathrm{CO})_{10}\{\mu-1,2-\mathrm{W} 001\}\right]$ (top) and recovered catalyst (bottom). Data collected at $298 \mathrm{~K}$ in $\mathrm{CDCl}_{3}$. 



Figure S4. Mass spectra of $\left[\mathrm{H}_{4} \mathrm{Ru}_{4}(\mathrm{CO})_{10}\{\mu-1,2-\mathrm{W} 001\}\right]$ (top) and recovered catalyst (bottom). FAB MS (m/z): calc. 1620 , observed 1619 . 


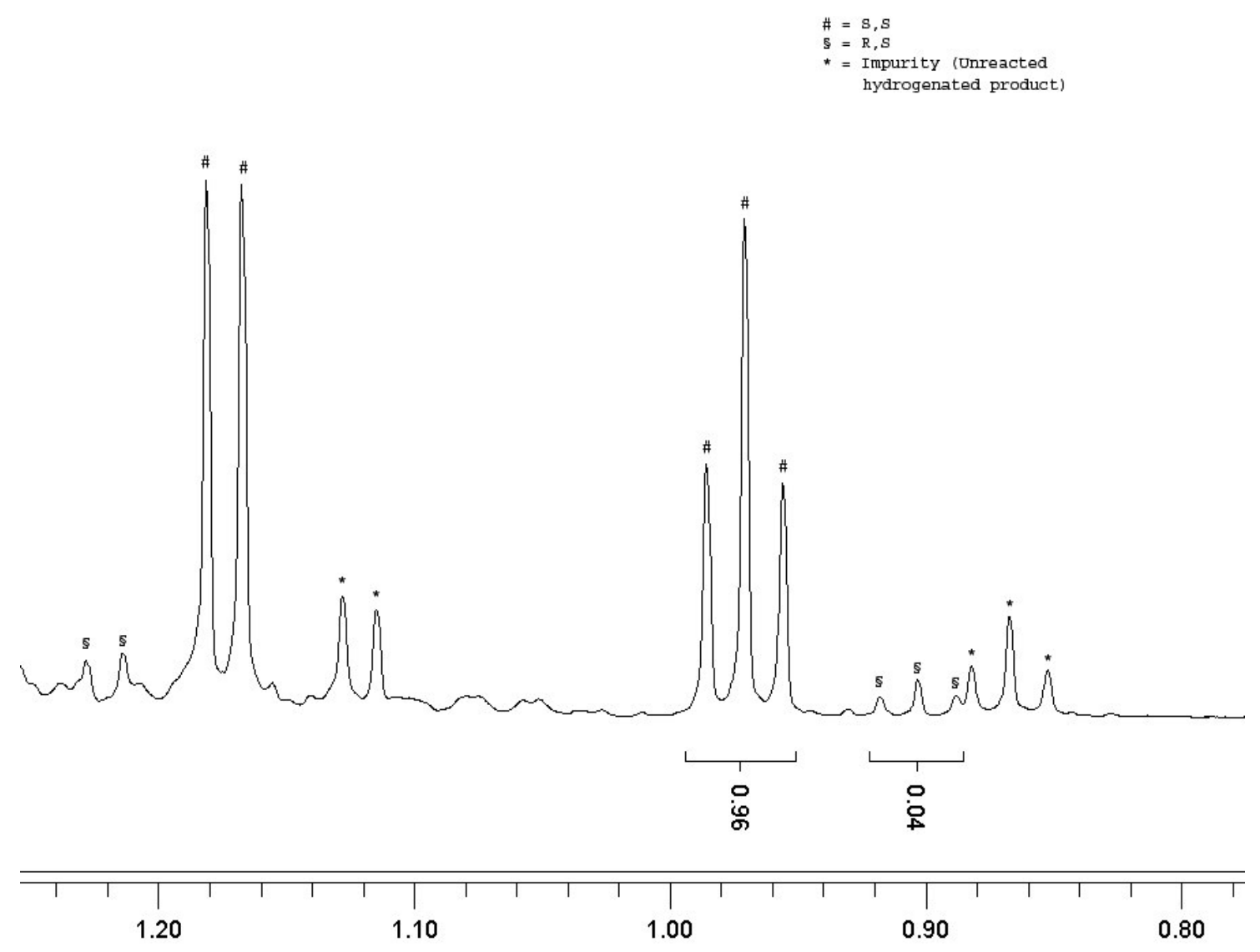

Figure S5a. Determination of enantiomeric excess by ${ }^{1} \mathrm{H}$ NMR spectroscopy of diastereomeric derivatives. Analysis of products from hydrogenation of tiglic acid using $\left[\mathrm{H}_{4} \mathrm{Ru}_{4}(\mathrm{CO})_{10}\{1,1-\mathrm{W} 001\}\right]$ 


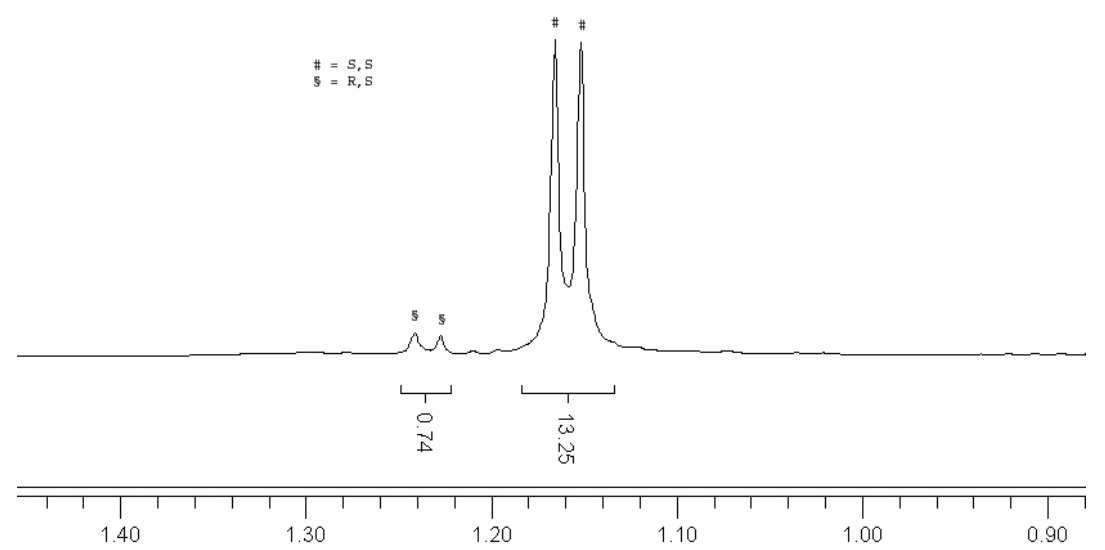

Figure S5b. Determination of enantiomeric excess by ${ }^{1} \mathrm{H}$ NMR spectroscopy of diastereomeric derivatives. Analysis of products from hydrogenation of aMCA using $\left[\mathrm{H}_{4} \mathrm{Ru}_{4}(\mathrm{CO})_{10}\{1,1-\mathrm{W} 001\}\right]$ 


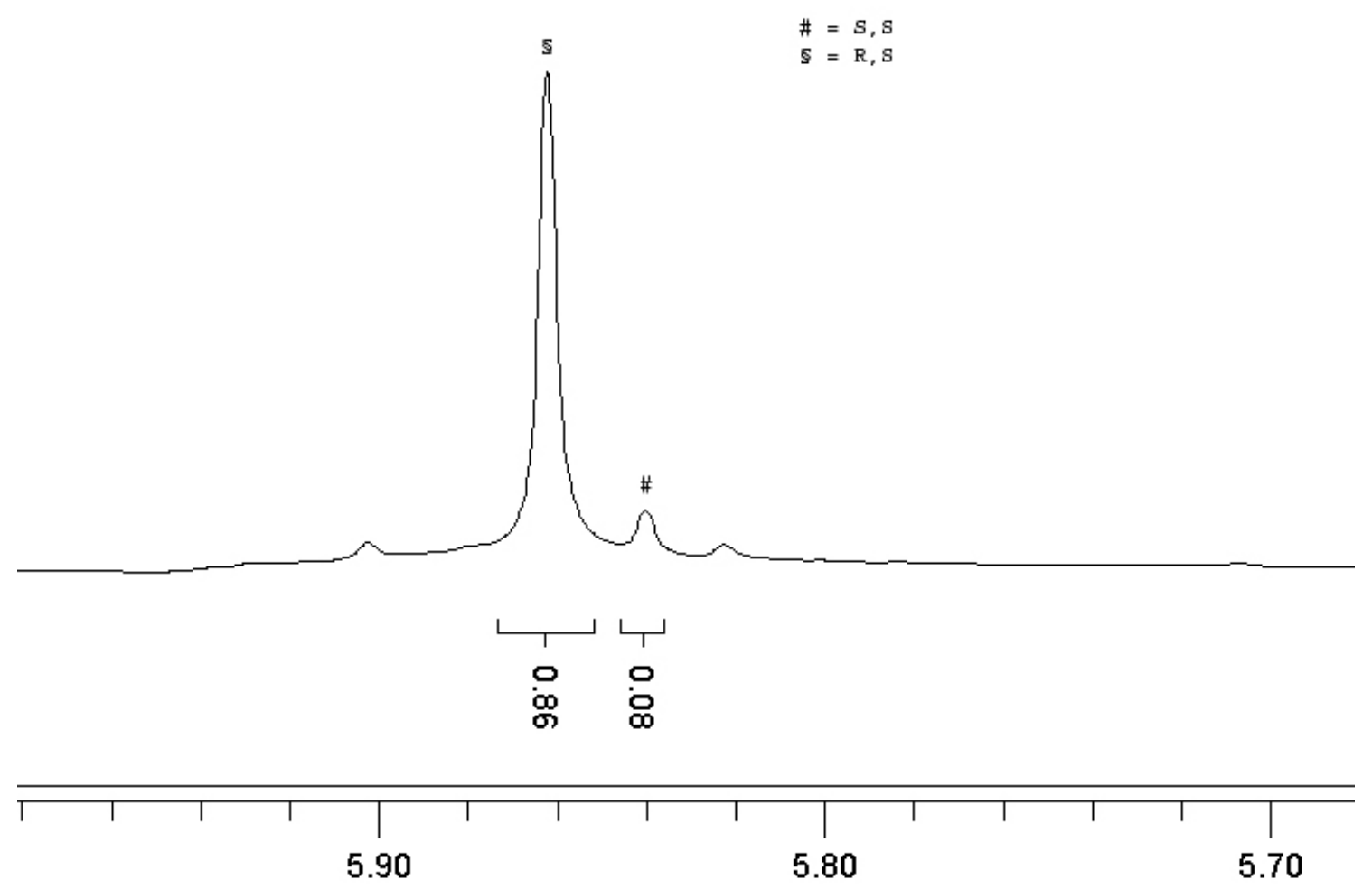

Figure S5c. Determination of enantiomeric excess by ${ }^{1} \mathrm{H}$ NMR spectroscopy of diastereomeric derivatives. Analysis of products from hydrogenation of aPCA using $\left[\mathrm{H}_{4} \mathrm{Ru}_{4}(\mathrm{CO})_{10}\{1,1-\mathrm{W} 001\}\right]$ 
$\#=S, S$
$\$=R, S$

* = Impurity (Unreacted

hydrogenated product)

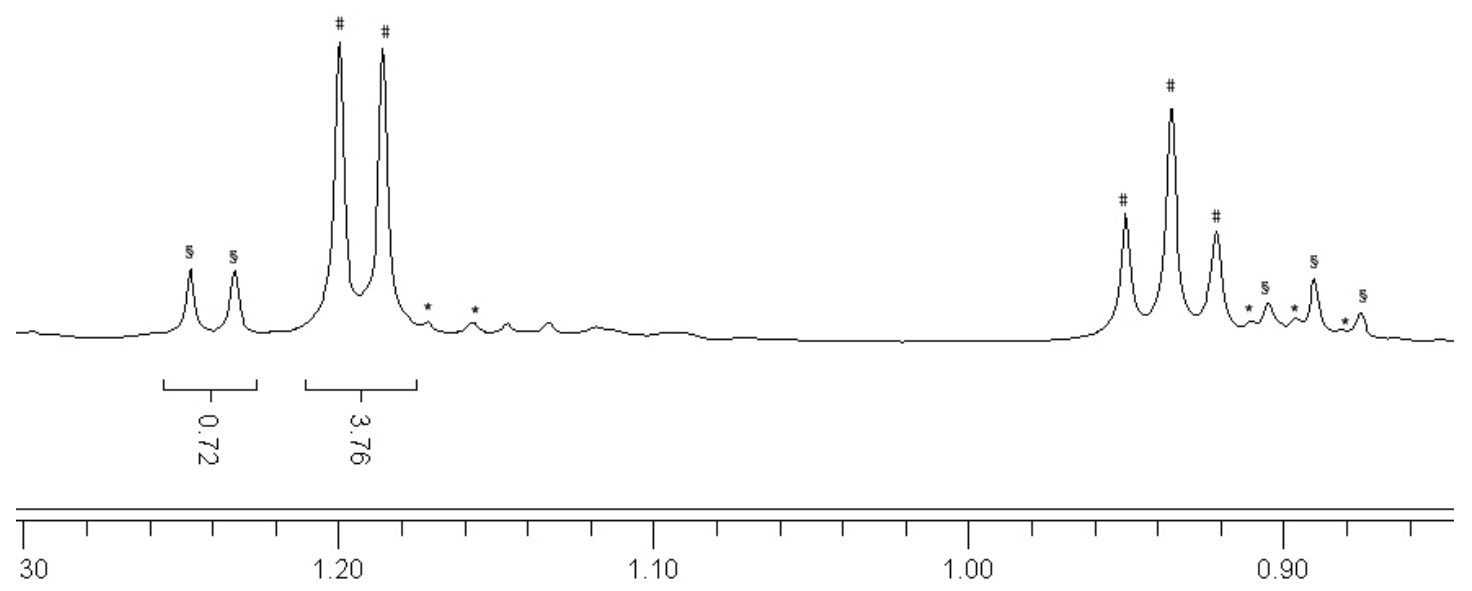

Figure S5d. Determination of enantiomeric excess by ${ }^{1} \mathrm{H}$ NMR spectroscopy of diastereomeric derivatives. Analysis of products from hydrogenation of tMPA using $\left[\mathrm{H}_{4} \mathrm{Ru}_{4}(\mathrm{CO})_{10}\{1,1-\mathrm{W} 001\}\right]$ 


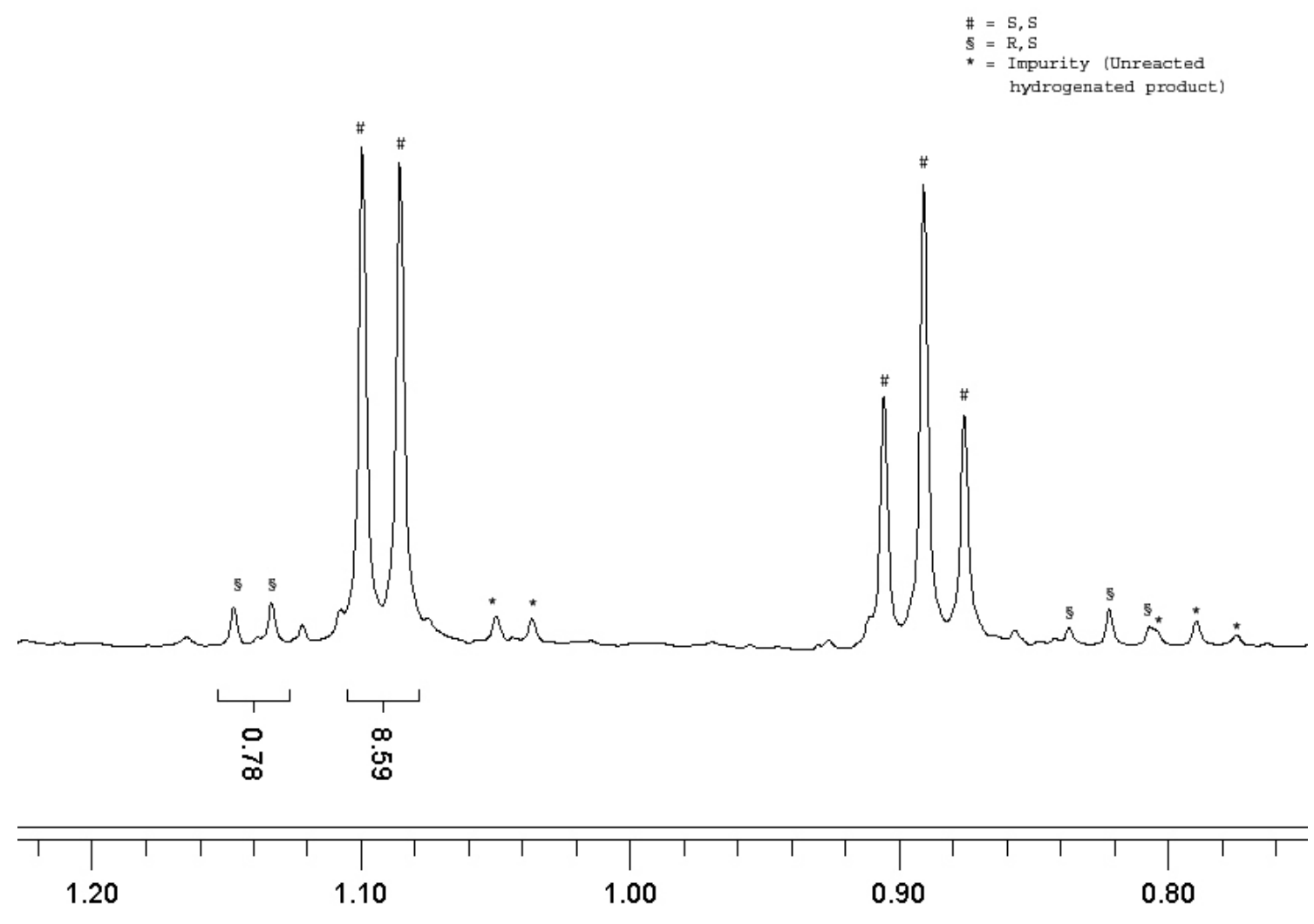

Figure S5e. Determination of enantiomeric excess by ${ }^{1} \mathrm{H}$ NMR spectroscopy of diastereomeric derivatives. Analysis of products from hydrogenation of tiglic acid using $\left[\mathrm{H}_{4} \mathrm{Ru}_{4}(\mathrm{CO})_{10}\{\mu-1,2-\mathrm{W} 001\}\right]$ 


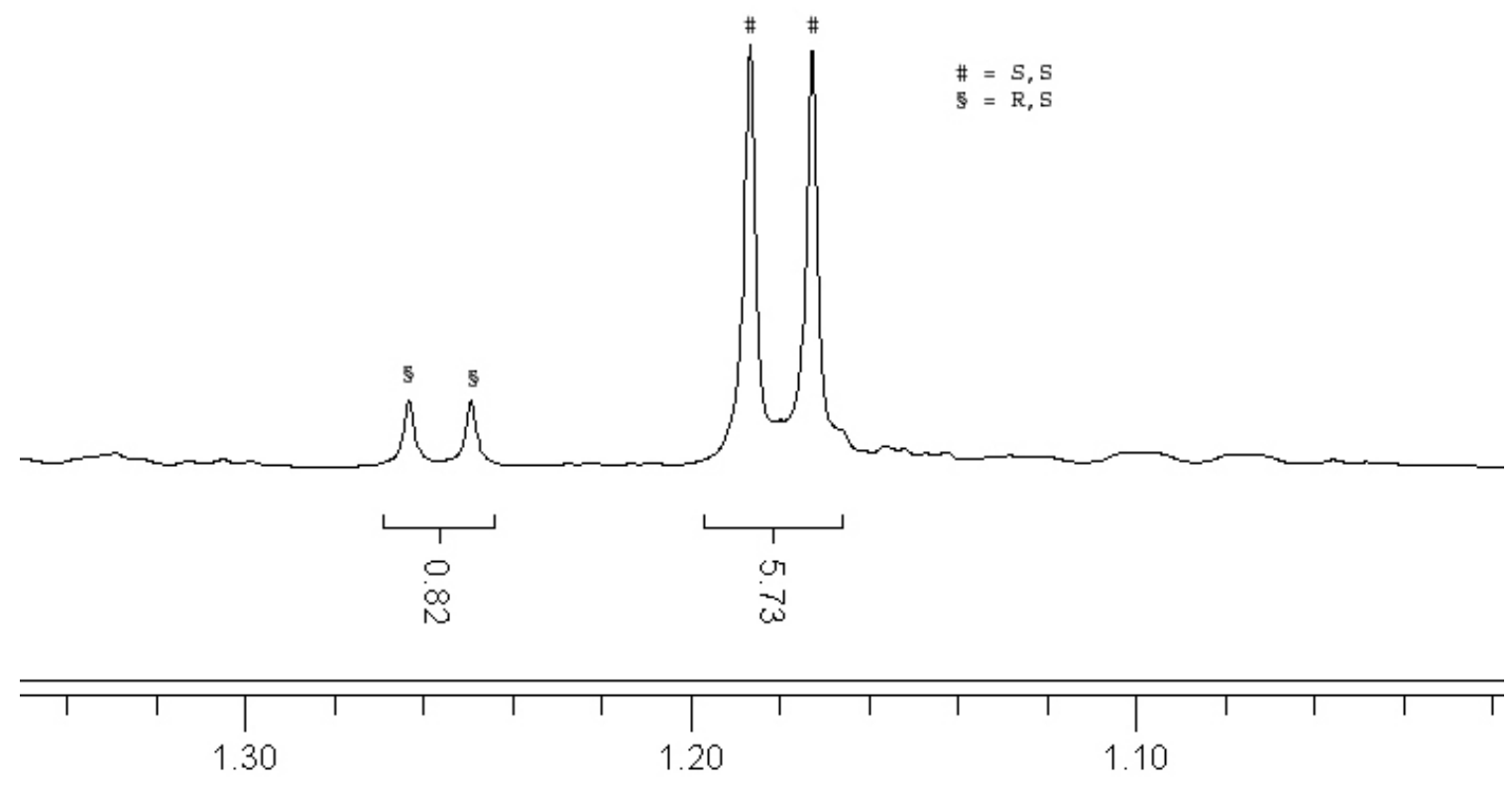

Figure S5f. Determination of enantiomeric excess by ${ }^{1} \mathrm{H}$ NMR spectroscopy of diastereomeric derivatives. Analysis of products from hydrogenation of aMCA using $\left[\mathrm{H}_{4} \mathrm{Ru}_{4}(\mathrm{CO})_{10}\{\mu-1,2-\mathrm{W} 001\}\right]$ 


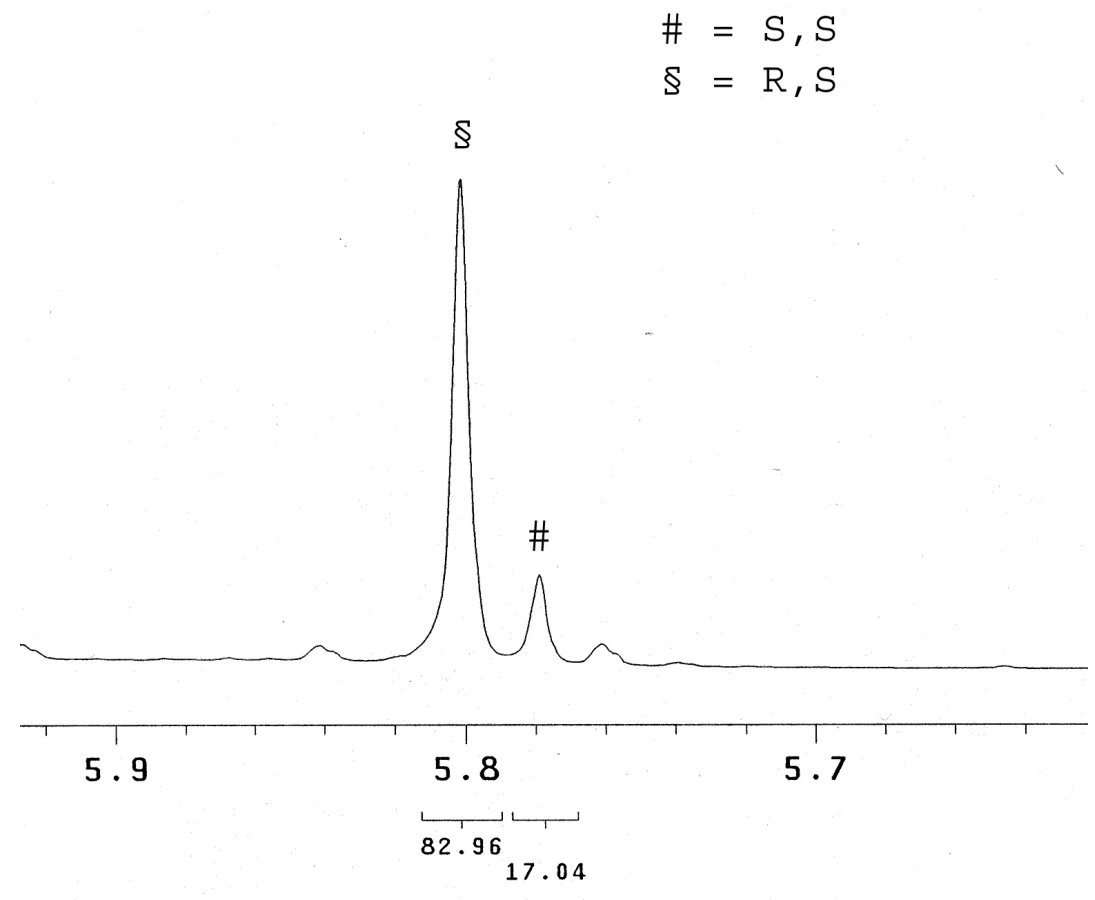

Figure S5g. Determination of enantiomeric excess by ${ }^{1} \mathrm{H}$ NMR spectroscopy of diastereomeric derivatives. Analysis of products from hydrogenation of aPCA using $\left[\mathrm{H}_{4} \mathrm{Ru}_{4}(\mathrm{CO})_{10}\{\mu-1,2-\mathrm{W} 001\}\right]$ 

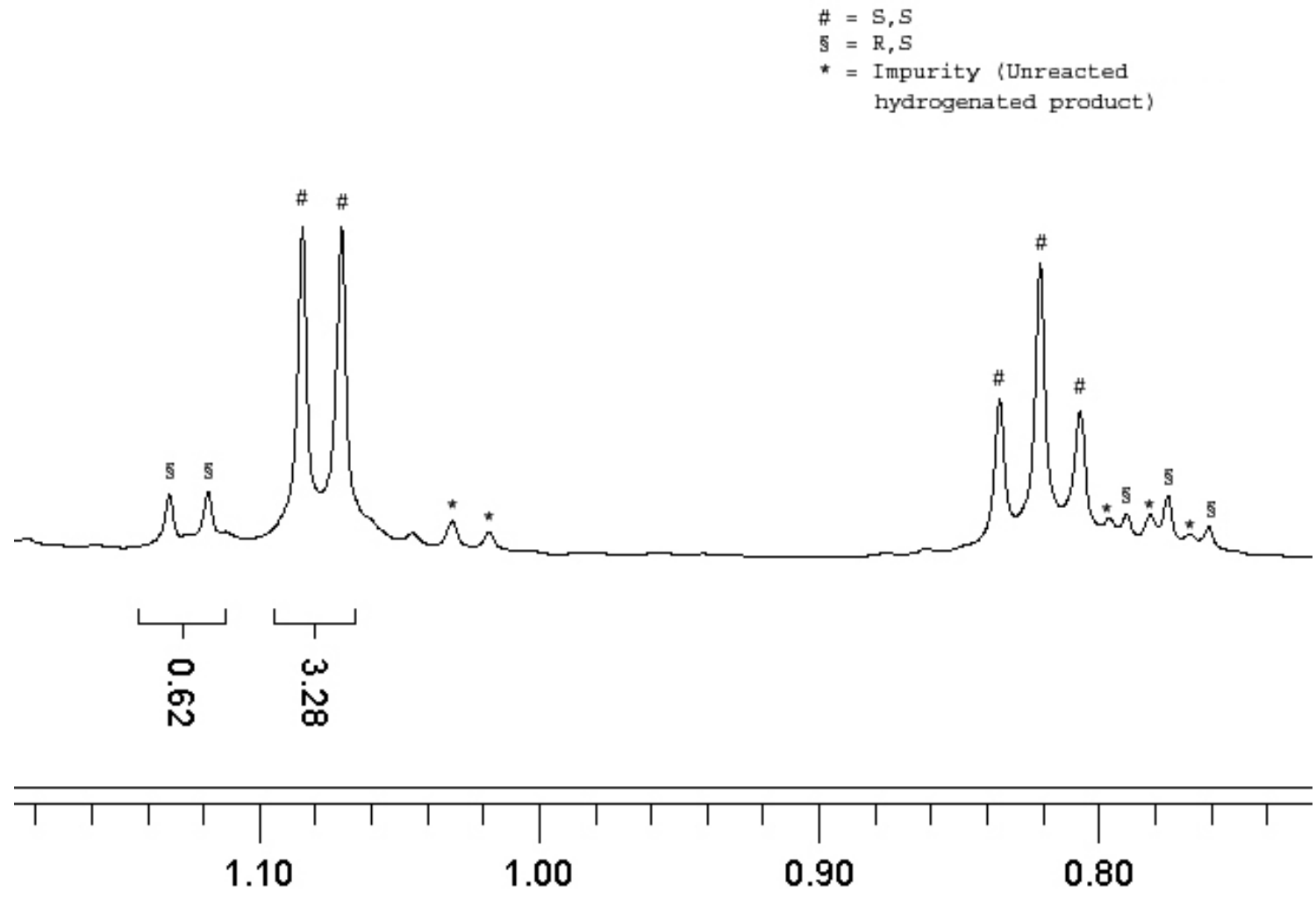

Figure S5h. Determination of enantiomeric excess by ${ }^{1} \mathrm{H}$ NMR spectroscopy of diastereomeric derivatives. Analysis of products from hydrogenation of tMPA using $\left[\mathrm{H}_{4} \mathrm{Ru}_{4}(\mathrm{CO})_{10}\{\mu-1,2-\mathrm{W} 001\}\right]$ 
$\#=S, S$

$s=\mathrm{R}, \mathrm{S}$

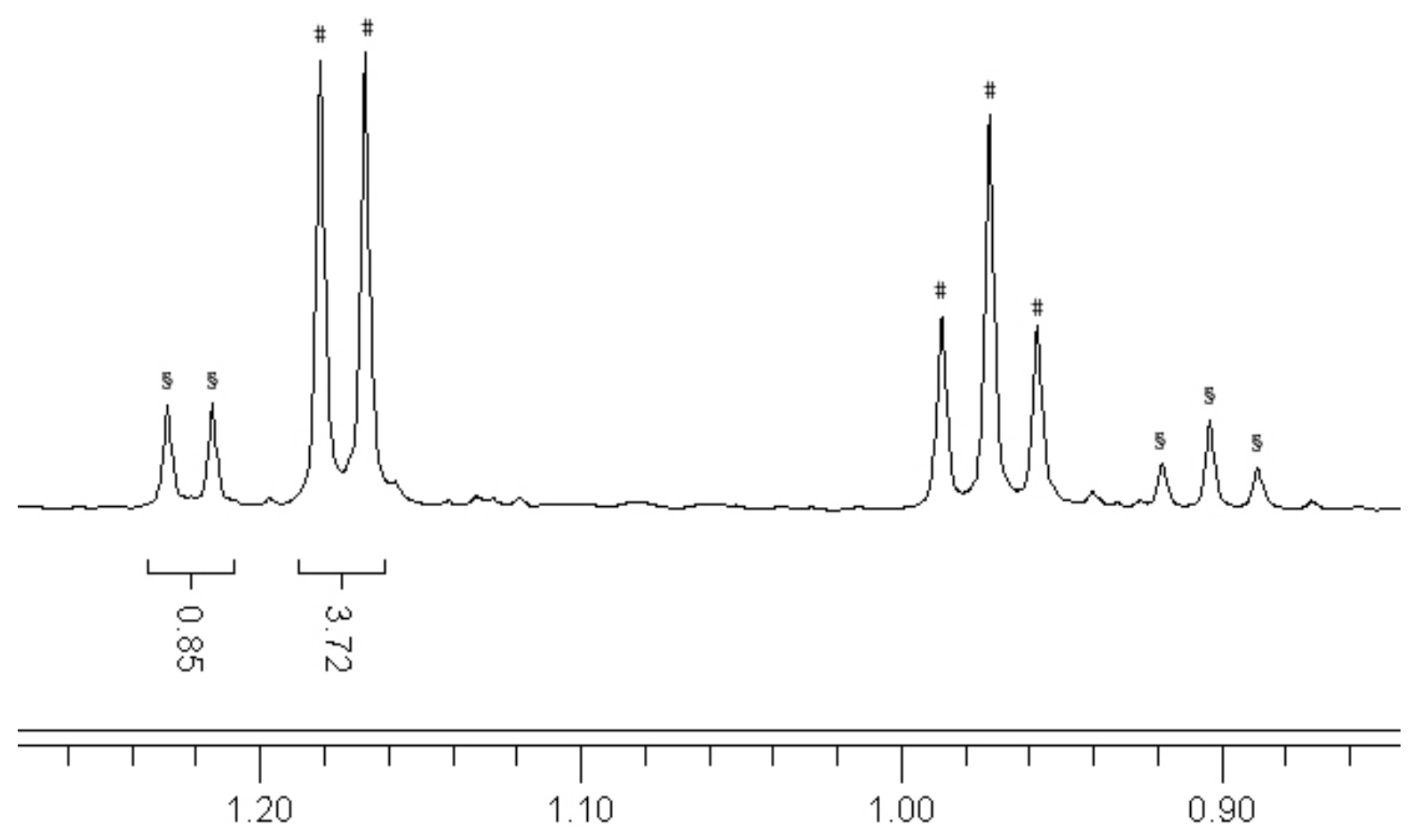

Figure S5i. Determination of enantiomeric excess by ${ }^{1} \mathrm{H}$ NMR spectroscopy of diastereomeric derivatives. Analysis of products from hydrogenation of tiglic acid using $\left[\mathrm{H}_{4} \mathrm{Ru}_{4}(\mathrm{CO})_{10}\{1,1-\mathrm{W} 002\}\right]$ 
$\#=S, 5$

$\mathrm{S}=\mathrm{R}, \mathrm{S}$

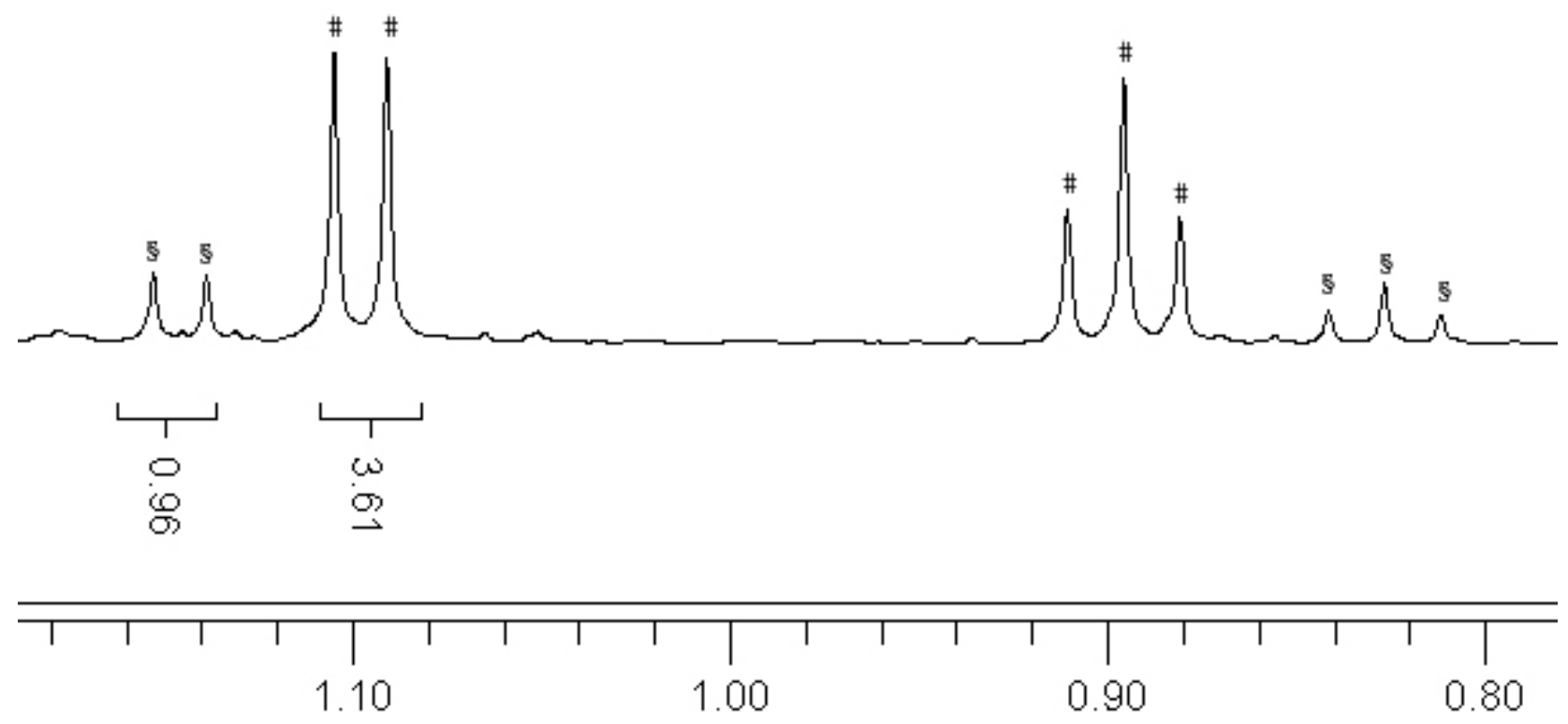

Figure S5j. Determination of enantiomeric excess by ${ }^{1} \mathrm{H}$ NMR spectroscopy of diastereomeric derivatives.

Analysis of products from hydrogenation of tiglic acid using $\left[\mathrm{H}_{4} \mathrm{Ru}_{4}(\mathrm{CO})_{10}\{\mu-1,2-\mathrm{W} 002\}\right]$ 

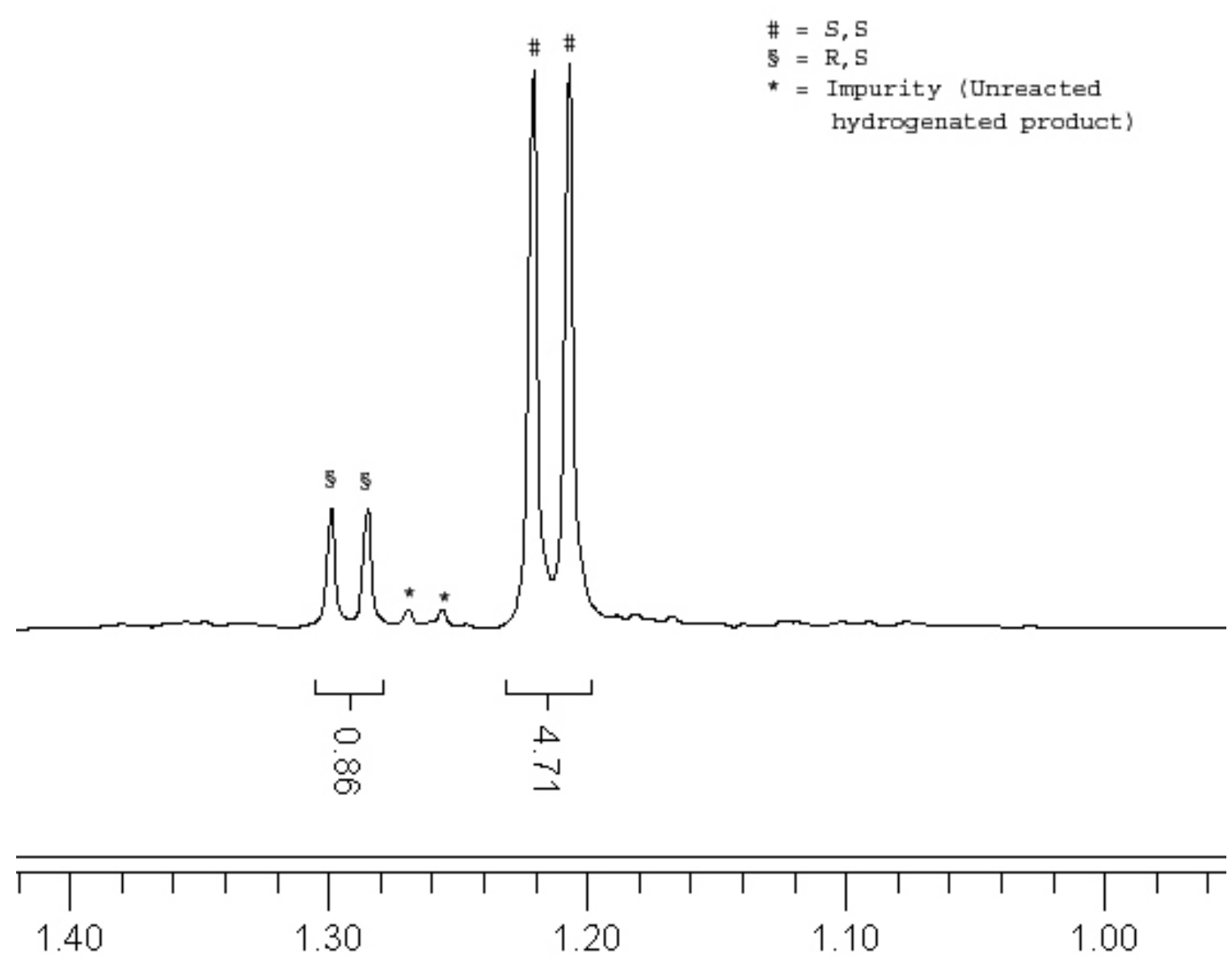

Figure S5k. Determination of enantiomeric excess by ${ }^{1} \mathrm{H}$ NMR spectroscopy of diastereomeric derivatives. Analysis of products from hydrogenation of aMCA using $\left[\mathrm{H}_{4} \mathrm{Ru}_{4}(\mathrm{CO})_{10}\{\mu-1,2-\mathrm{W} 002\}\right]$ 


$$
\begin{aligned}
& \#=S, S \\
& \S=R, R
\end{aligned}
$$

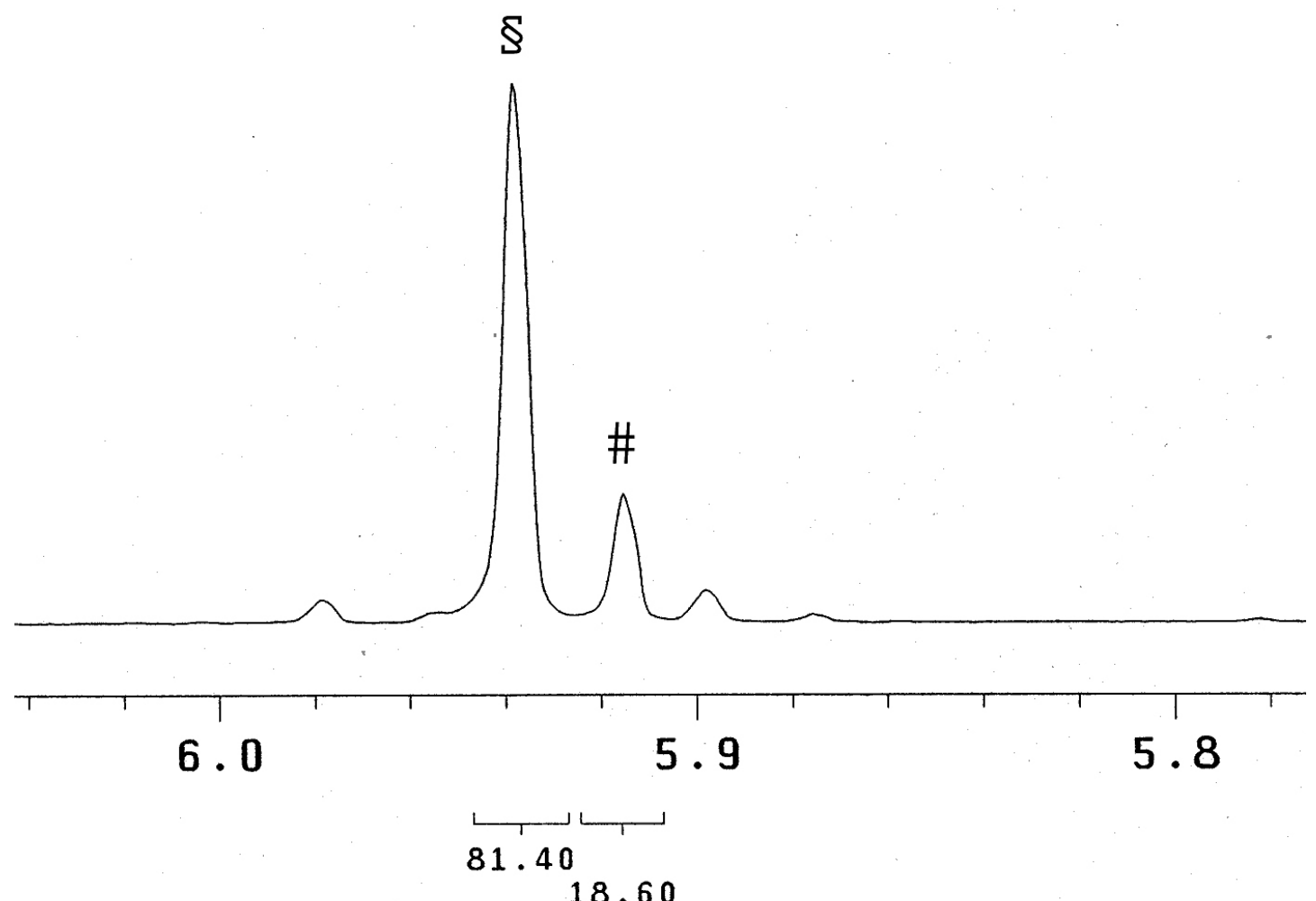

Figure S5l. Determination of enantiomeric excess by ${ }^{1} \mathrm{H}$ NMR spectroscopy of diastereomeric derivatives. Analysis of products from hydrogenation of aPCA using $\left[\mathrm{H}_{4} \mathrm{Ru}_{4}(\mathrm{CO})_{10}\{\mu-1,2-\mathrm{W} 002\}\right]$ 


$$
\begin{aligned}
\#= & \mathrm{S}, \mathrm{S} \\
\S= & \mathrm{R}, \mathrm{S} \\
*= & \text { Impurity (Unreacted } \\
& \text { hydrogenated product) }
\end{aligned}
$$

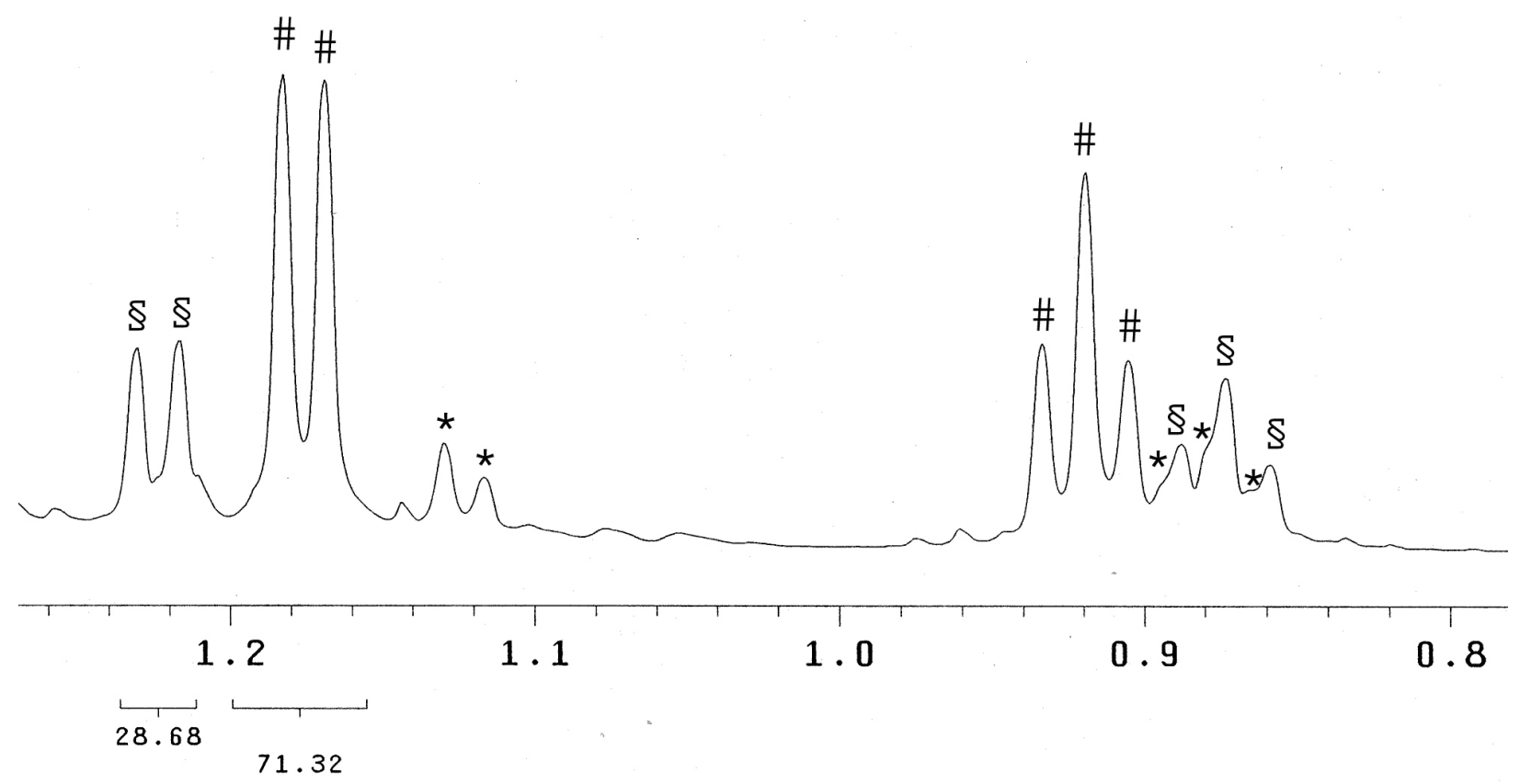

Figure S5l. Determination of enantiomeric excess by ${ }^{1} \mathrm{H}$ NMR spectroscopy of diastereomeric derivatives. Analysis of products from hydrogenation of tMPA using $\left[\mathrm{H}_{4} \mathrm{Ru}_{4}(\mathrm{CO})_{10}\{\mu-1,2-\mathrm{W} 002\}\right]$ 


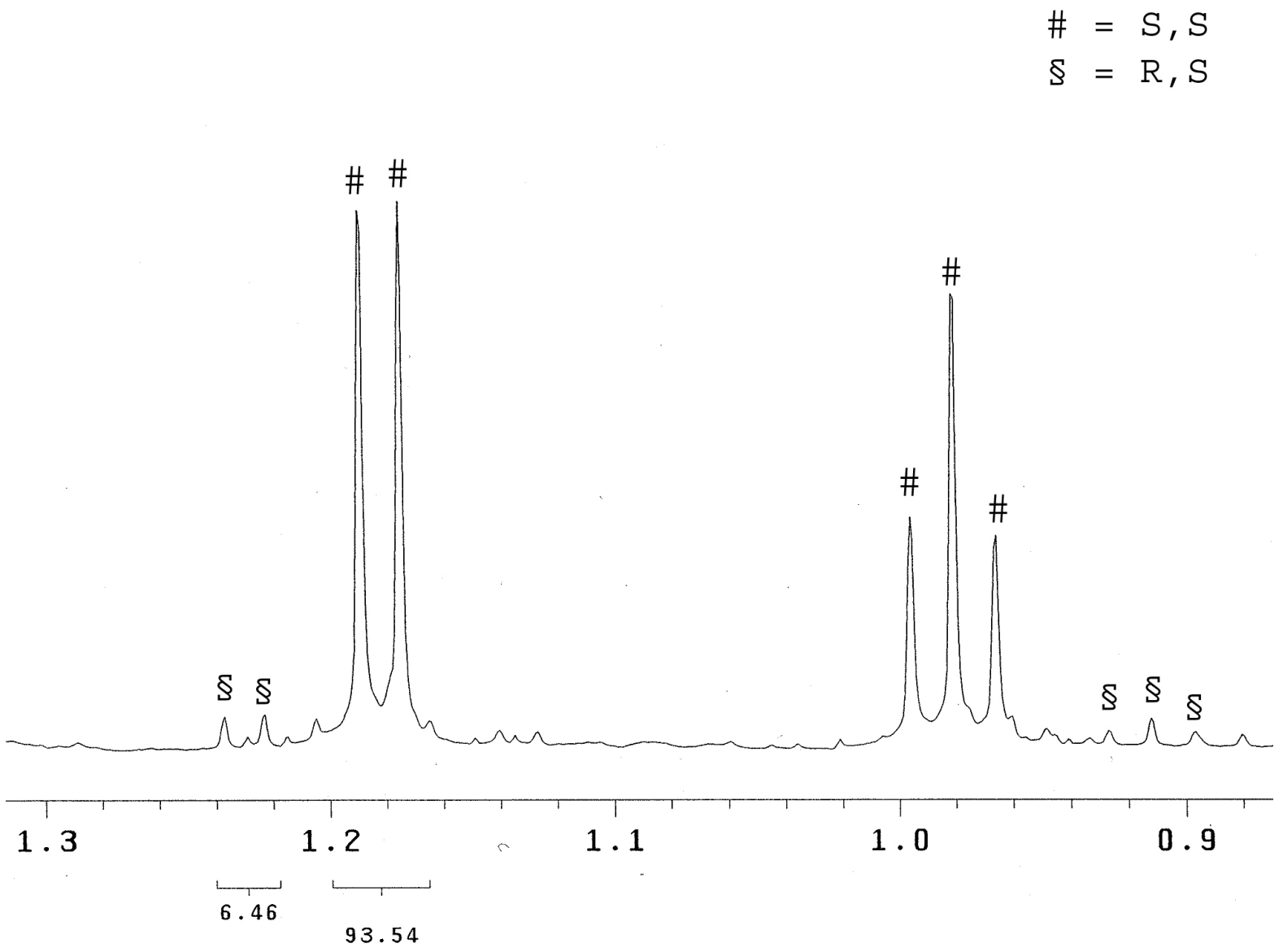

Figure S5j. Determination of enantiomeric excess by ${ }^{1} \mathrm{H}$ NMR spectroscopy of diastereomeric derivatives. Analysis of products from hydrogenation of tiglic acid using $\left[\mathrm{H}_{4} \mathrm{Ru}_{4}(\mathrm{CO})_{10}\{\mu-1,2-\mathrm{W} 001\}\right] / \mathrm{Hg}(0)$. 


$$
\begin{aligned}
\#= & \mathrm{S}, \mathrm{S} \\
\S= & \mathrm{R}, \mathrm{R} \\
\text { * } & \text { Impurity (Unreacted } \\
& \text { hydrogenated product) }
\end{aligned}
$$

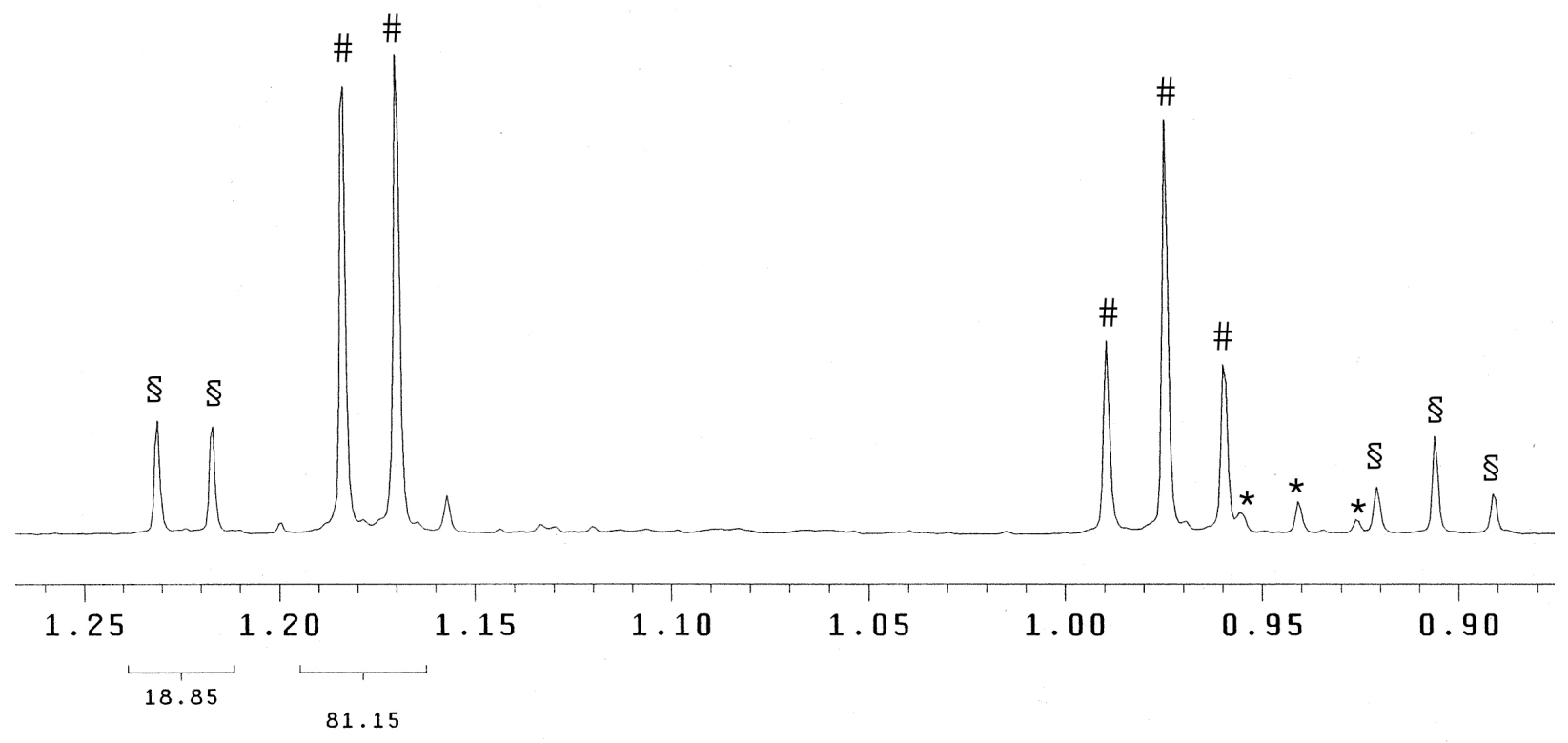

Figure S5k. Determination of enantiomeric excess by ${ }^{1} \mathrm{H}$ NMR spectroscopy of diastereomeric derivatives. Analysis of products from hydrogenation of tiglic acid using $\left[\mathrm{H}_{4} \mathrm{Ru}_{4}(\mathrm{CO})_{10}\{\mu-1,2-\mathrm{W} 002\}\right] / \mathrm{Hg}(0)$. 

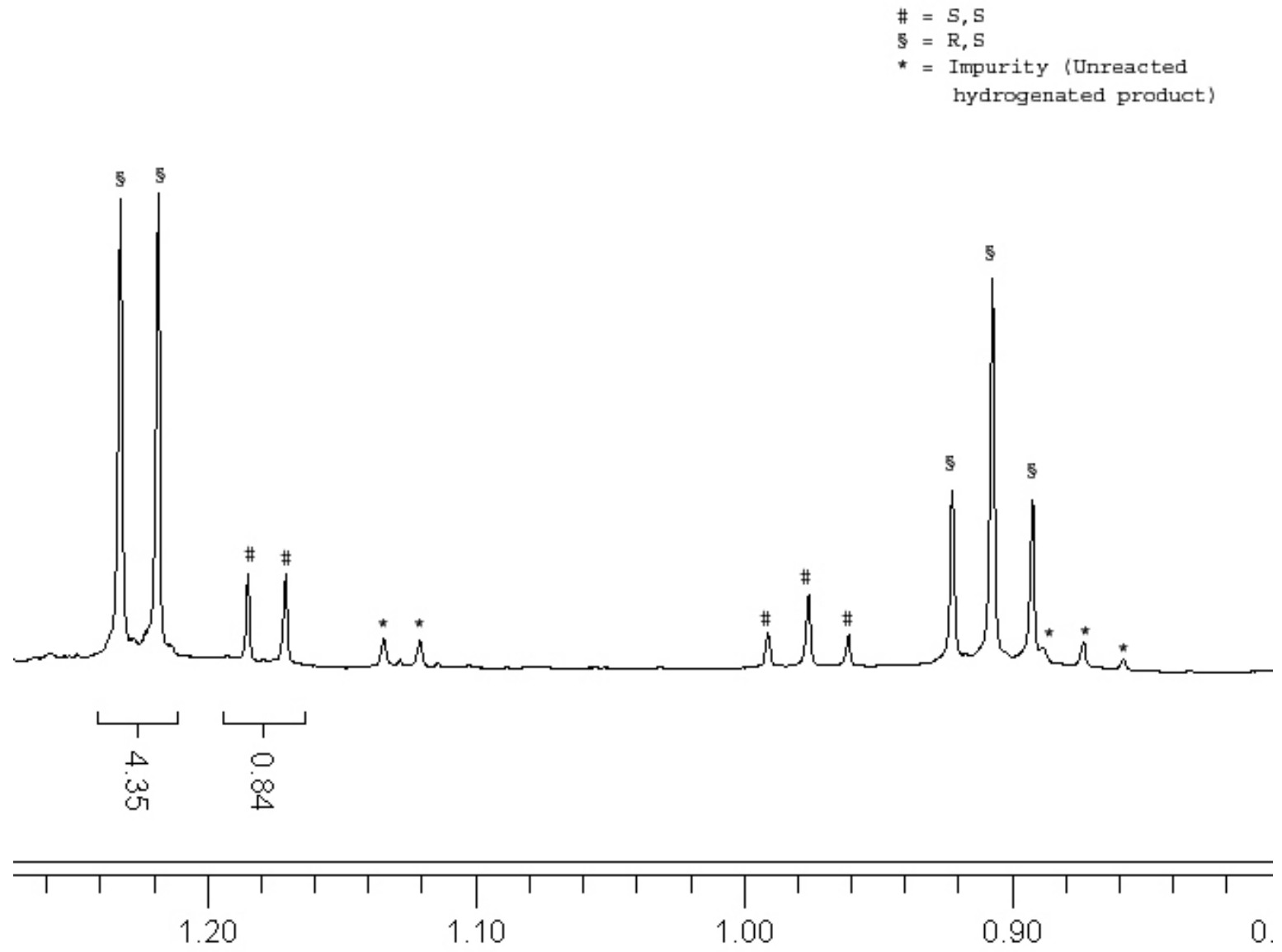

Figure S51. Determination of enantiomeric excess by ${ }^{1} \mathrm{H}$ NMR spectroscopy of diastereomeric derivatives. Analysis of products from hydrogenation of tiglic acid using $\left[\mathrm{Ru}(\mathrm{II})(R\right.$-BINAP $\left.)(\mathrm{OAc})_{2}\right]$ 


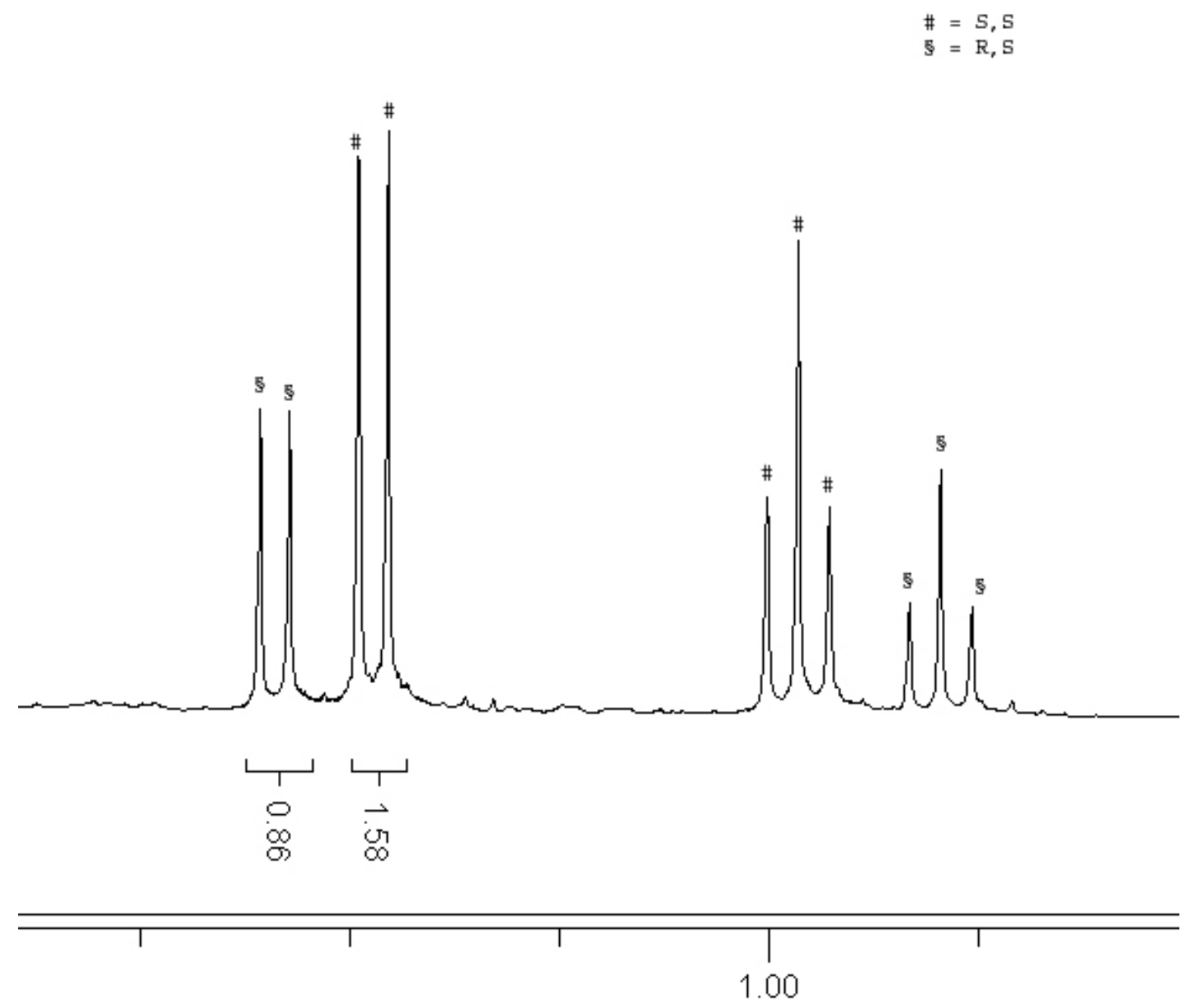

Figure S5m. Determination of enantiomeric excess by ${ }^{1} \mathrm{H}$ NMR spectroscopy of diastereomeric derivatives. Analysis of products from hydrogenation of tiglic acid using $\left[\mathrm{Ru}(\mathrm{II})(\mathrm{W} 001)(\mathrm{OAc})_{2}\right]$ 